\title{
Structural and luminescent characterisation of uraniferous fluorapatite and haematite associated with phosphatic rocks of the Bijawar group in Sagar District, Madhya Pradesh (India)
}

\author{
Pragya Pandit ${ }^{1, *}$, Shailendra Kumar ${ }^{1}$, Pargin Bangotra ${ }^{2}$, Rohit Mehra ${ }^{2}$, \\ Manoj Mohapatra ${ }^{3}$, Madhuparna Roy ${ }^{1}$ and A K Singh ${ }^{4}$ \\ ${ }^{1}$ Atomic Minerals Directorate for Exploration and Research, New Delhi 110 066, India. \\ ${ }^{2}$ Dr. B.R. Ambedkar National Institute of Technology, Jalandhar 144 011, India. \\ ${ }^{3}$ Radiochemistry Division, Bhabha Atomic Research Center, Mumbai 400 085, India. \\ ${ }^{4}$ Maharaja Surajmal Institute of Technology, USICT, GGSIPU, New Delhi 110 058, India. \\ *Corresponding author. e-mail: pragyapandit.amd@gov.in
}

MS received 9 October 2017; revised 19 February 2018; accepted 26 February 2018; published online 29 September 2018

The structural and spectroscopic characteristics of phosphatic ferruginous shale samples from the Bijawar Group rocks from Sagar District of Madhya Pradesh (India) have been probed for identification of uranium species. Fluorapatite $\left(\mathrm{Ca}_{5}\left(\mathrm{PO}_{4}\right)_{3} \mathrm{~F}, \mathrm{FAP}\right)$ and haematite $\left(\alpha-\mathrm{Fe}_{2} \mathrm{O}_{3}\right)$ were identified as the main phases in the separated mineral concentrates. The photoluminescence (PL) and X-ray absorption near edge spectroscopy (XANES) studies pointed to a strong experimental evidence of both U(IV) and U(VI) oxidation states in the mineral concentrate portion obtained from the same parent host rock. The PL spectrum has confirmed the charge transfer $(\mathrm{f}-\mathrm{d})$ transition bands in UV and near-UV regions with emission peaks at ca. 290, 313, 336, 399 and $416 \mathrm{~nm}$, which has been attributed to the substitution of $\mathrm{Ca}^{2+}$ ions by U(IV) in FAP and broad structureless emission due to stabilisation of U(VI) as $\mathrm{UO}_{6}^{6-}$ in haematite. Time-resolved spectroscopy studies have revealed biexponential decay components lasting 2-5 ns for U(IV) species and $10 \mu \mathrm{s}$ for U(VI) species. These characterisations revealed the fundamental information about the oxidation state and form of uranium in this region. Remediation measures for the Bijawar region are also suggested.

Keywords. Uranium; photoluminescence; X-ray absorption spectroscopy; X-ray diffraction.

\section{Introduction}

The need for nuclear self-sufficiency and the growing gap between energy demand and supply has necessitated the country to utilise modest (low and intermediate) indigenous uranium reserves. Phosphate deposits are large potential sources of low-grade (0.005-0.020\%) uranium reserves worldwide (Guzman et al. 1995). In India, the total reserve of rock phosphates is about 296.3 million

Supplementary material pertaining to this article is available on the Journal of Earth System Science website (http://www. ias.ac.in/Journals/Journal_of_Earth_System_Science). 
tons, which could serve as a significant secondary source of uranium. The Proterozoic Bijawar basin exposed along the southeastern margin of the Bundelkhand massif is an area of interest for uranium exploration associated with phosphatic rocks, which offers a substantial quantity of low-grade uranium (Banerjee et al. 1982; Roy et al. 2004; Dar et al. 2014a). The uranium mineralisation in the Bijawar basin is hosted by phosphatic ferruginous shale breccia and the average concentration of uranium varies approximately between $0.015 \%$ and $0.1 \%$.

Previous structural and spectroscopic characterisation studies conducted in the Bijawar region and Palaeoproterozoic phosphorites of the Sonrai basin by X-ray diffraction (XRD), scanning electron microscopy (SEM) and inductively coupled plasma emission spectroscopy (ICP-AES) (Dar et al. 2014a, b) have focused on the determination of trace metallic constituents and phase analysis of the samples of this region; however, so far no report is available on the uranium species present in this region. The major analytic challenges in the speciation and spectroscopic characterisation of uranium species in the Bijawar region are their low concentration and interference due to the heterogeneous elements in the complex rock matrix. The present study is concerned with the characterisation and speciation of uranium in the Bijawar region.

An important key to understanding the uranium retention process (adsorption, precipitation or association with minerals) is to identify the uranium species. The mobilisation and deposition of uranium rely on its speciation which further depends on the geological, geochemical and hydrogeological process in the host environment. A basic understanding at the molecular level is required for understanding the uranium speciation. Hence, the techniques that can be used as a diagnostic tool at the molecular level such as luminescence spectroscopy, X-ray absorption spectroscopy (XAS) and Raman spectroscopy are employed.

In the present investigations, a comprehensive photoluminescence (PL) study along with lifetime decay by time-resolved photoluminescence (TRPL) has been performed on the sample from the Bijawar region to determine uranium oxidation states and the uranium moiety associated with these oxidation states. The PL results are further substantiated with structural, microstructural and spectroscopic characterisation performed using X-ray absorption near edge spectroscopy
(XANES), XRD, Raman spectroscopy, Fourier transform infrared (FTIR) spectra and SEM. The PL and XANES successfully identified the oxidation state and the uranium species associated with them instead of Raman, XRD and FTIR. This study aims to provide baseline information on the speciation of uranium in this region. The results of this study have been utilised to infer the state of uranium in the investigated mineral phase e.g., fluorapatite $\left(\mathrm{Ca}_{5}\left(\mathrm{PO}_{4}\right)_{3} \mathrm{~F}, \mathrm{FAP}\right)$ and haematite. Also, the data has been utilised to evaluate the remediation aspects of this region.

\section{Geology}

The Bijawar region is located in the Chattarpur district of Madhya Pradesh, India (figure 1). The Palaeoproterozoic metasedimentary rocks of the Bijawar Group resting upon the Archean Bundelkhand Basement Complex are overlain by the rocks of the Vindhyan Supergroup (Jha et al. 2012). The study area constituted the Proterozoic Bijawar basin spread over along the southeastern margin of the Bundelkhand massif. The northern margin of the basin is marked by an unconformity with different formations of the Bijawar Group predominantly comprising arenaceous with subordinate dolomitic units resting unconformably over the Bundelkhand Granite Gneiss. Along the southern margin of the basin, the Bijawar sediments are unconformably overlain by the middle Proterozoic clastic sediments of the Semri Group (Vindhyans). The uranium mineralisation in this area is hosted by ferruginous shale breccia with angular and subrounded fragments of quartz in the Lower Proterozoic Karri Ferruginous Formation (KFF) of upper Bijawar Group to the north of contact with Vindhyan sediments.

\section{Methodology}

The ferruginous shale sample $\mathrm{SH}-9$ for structural and spectroscopic characterisation was collected from the Bijawar region during field season 20142015 during reconnaissance survey $\left(24^{\circ} 20^{\prime} 52.5^{\prime \prime} \mathrm{N}\right.$, $\left.79^{\circ} 12^{\prime} 51^{\prime \prime} \mathrm{E}\right)$. The SH-9 sample is a typical combination of FAP, iron oxides, hydroxides and oxyhydroxides along with cementitious silica, quartz and clay mineral. The optical microscopy and solid-state nuclear track detector (SSNTD) studies conducted on the sample have indicated Fe-rich material (haematite) and FAP as the main uranium-bearing radioactive phases 


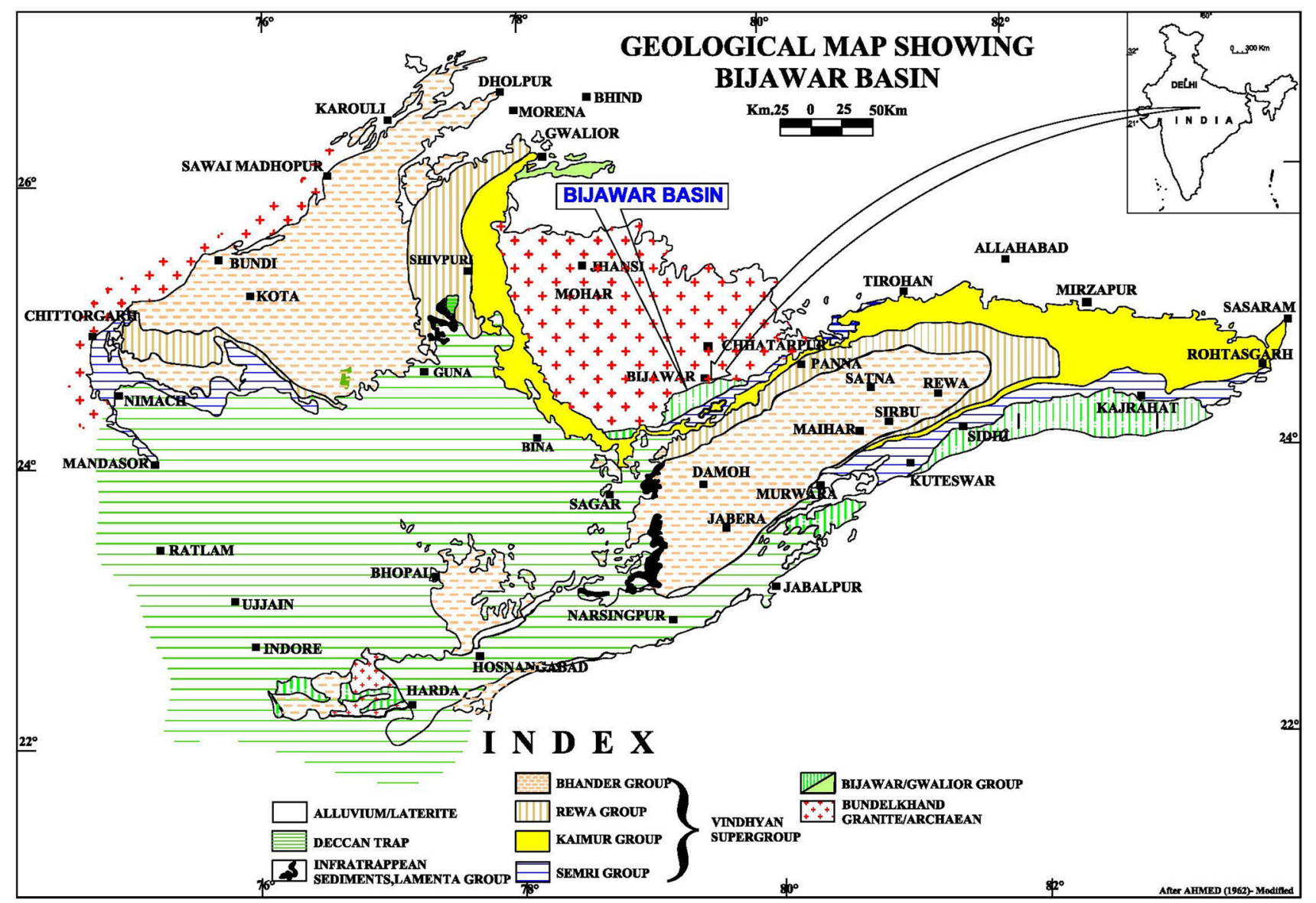

Figure 1. Geological map of the investigated area of the Bijawar basin.

(supplementary figure S1). The sample has clear partitioning available in the form of black and white portions constituting of FAP and haematite. The SH-9 was hence separated into FAP-bearing white portion called SH-9White (SH-9W) and haematite-bearing black portion hereby called SH9Black (SH-9B). The representative subsamples of $100 \mathrm{~g}$ quantity from each of the lots, SH-9W and $\mathrm{SH}-9 \mathrm{~B}$, were powdered (mesh size -60 ) and homogenised by coning and quartering. The subsample from the homogenised lot was taken and the bulk uranium concentration in the samples was measured using $\mathrm{NaI}(\mathrm{Tl})$ gamma detector of size $5^{\prime \prime} \times 4^{\prime \prime}$ with a multichannel analyser. The percentage of $\mathrm{U}_{3} \mathrm{O}_{8}$ content in $\mathrm{SH}-9 \mathrm{~W}$ and SH-9B is identified to be $0.17 \%$ and $0.053 \%$, respectively. In order to beneficiate the corresponding minerals, the samples were crushed to size $(0.15 \mathrm{~mm}<$ grain size $<0.17 \mathrm{~mm})$ and subjected to heavy liquid separation. The crushed samples were first subjected to bromoform separation (specific gravity, $\rho=2.89 \mathrm{~g} / \mathrm{cm}^{3}$ ) to selectively concentrate the mineral species. The bromolight portion of the samples consisting of quartz, mica and clay minerals was discarded and bromoheavy portion containing uranium species for both mineral concentrates was further subjected to methylene iodide $\left(\rho=3.35 \mathrm{~g} / \mathrm{cm}^{3}\right)$ separation. This mineral concentrate portion of both SH-9W and SH-9B was selected for the analysis. Phase purity and crystal structure of the mineral concentrate samples were identified by X-ray diffractometer using $\mathrm{Cu} \mathrm{K} \alpha_{1}$ radiation (1.5406 $\AA$ ) fitted with a $\mathrm{Ni}$ filter in $\theta-2 \theta$ mode (Rigaku). The data was collected from $20^{\circ}$ to $70^{\circ}$ with a step size of $0.02^{\circ}$. Simulation of crystal structure based on the measured XRD data was carried out using the refinement software. Surface morphology along with qualitative and semi-quantitative analysis of the fractured mineral was analysed with the field emission scanning electron microscope (Carl-Zeiss, SUPRA 40) equipped with Xray energy dispersive spectroscopy. Raman spectra were obtained using a Raman spectrometer with an excitation source of $785 \mathrm{~nm}$ with spectral resolution of $1 \mathrm{~cm}^{-1}$ (Renishaw inVia). Infrared absorption spectra were taken in the range $400-4000 \mathrm{~cm}^{-1}$ using FTIR using the standard $\mathrm{KBr}$ technique 
(Perkin-Elmer). The optical absorption was measured in the spectral range 190-700 nm using UV-Vis-NIR spectrometer (UV 3101 PC Shimadzu). The photoluminescence (PL and PLE) spectra were measured using an FLS920 fluorescence spectrometer (Edinburgh Instruments Ltd.). For excitation, a $450 \mathrm{~W}$ ozone-free xenon arc lamp has been used as a standard light source. TRPL measurements in the nanosecond and microsecond decay scales were performed by nanosecond (ns) pulse diode laser $\left(\lambda_{\text {exc }}=285 \mathrm{~nm}\right.$, pulse duration $750 \mathrm{ps}$ and repetition frequency $5 \mathrm{MHz}$ ) and a xenon microsecond $(\mu \mathrm{s})$ flash lamp using the FLS920 lifetime spectrometer (Edinburgh Instruments Ltd.). XANES spectra of the samples were recorded in fluorescence mode at $\mathrm{U} \mathrm{L}_{\mathrm{III}}$-edge $(17,116 \mathrm{eV})$ and those standards were taken in transmission mode using the vortex energy detector at BL-9, scanning X-ray absorption fluorescence spectroscopy beamline of INDUS-2 synchrotron source $(2.5 \mathrm{GeV}, 100 \mathrm{~mA})$ at Raja Ramanna Center for Advanced Technology (RRCAT), Indore.

\section{Results and discussion}

The structural and spectroscopic characterisation pertaining to SH-9W (FAP) and SH-9B (haematite) is discussed below.

\subsection{X-ray diffraction}

\subsubsection{Fluorapatite}

The qualitative analysis of the XRD revealed FAP to be the main phase of SH-9W (figure 2a). The intense $2 \theta$ reflections at $25.89^{\circ}, 29.01^{\circ}, 31.90^{\circ}$, $32.20^{\circ}, 33.10^{\circ}, 34.16^{\circ}, 39.94^{\circ}, 46.87^{\circ}, 49.57^{\circ}$ and $51.41^{\circ}$ corresponding to the $h \mathrm{kl}$ planes (002), (120), (121), (112), (300), (202), (310), (222), (123) and (410), respectively, were observed in agreement with the previous literature (JCPDS \#15-0876). Additional reflections corresponding to calcite were observed at $46^{\circ}, 54^{\circ}$ (JCPDS \# 05-0586) and at $24^{\circ}$ corresponding to haematite (JCPDS \#33-0664). The structure of FAP is a hexagonal belonging to the space group $P 6_{3} / m$ with unit cell
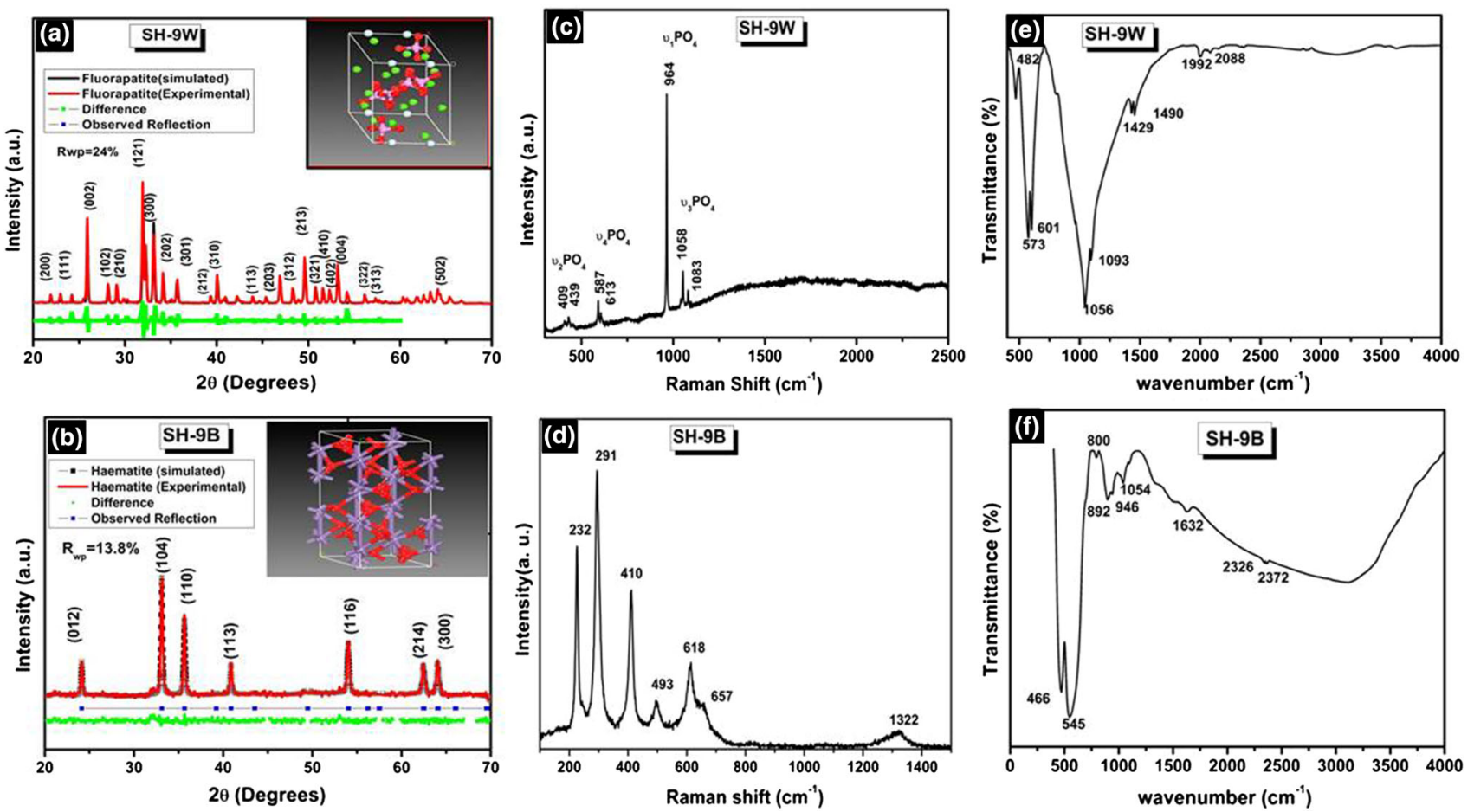

Figure 2. Structural characterisation of SH-9W and SH-9B showing the vibrational and structural information. The measured XRD patterns of (a) SH-9W showing predominantly FAP bands (the inset shows the schematic representation of the hexagonal structure of FAP with Ca atoms in green coordinated to phosphate tetrahedra in red and fluorine atoms in white) and (b) $\mathrm{SH}-9 \mathrm{~B}$ (the inset shows the schematic representation of the corundum structure of $\mathrm{Fe}_{2} \mathrm{O}_{3}$. The face-sharing and edge-sharing $\mathrm{FeO}_{6}$ octahedra are shown to be stacked parallel to the $c$-axis; $2 / 3$ of the octahedral sites are occupied by $\mathrm{Fe}^{3+}$ atoms. The red and blue spheres represent iron and oxygen, respectively). The figures shown are the orthographic views. (c) Raman spectra of SH-9W showing mainly the FAP bands, (d) Raman spectra of SH-9B, (e) FTIR pattern of SH-9W and (f) FTIR pattern of SH-9B. 
dimensions of $a=b=9.367 \AA, c=6.884 \AA$ and cell volume of $519.77 \AA^{3}$. The crystal refinement of the recorded XRD pattern was carried out by considering only the pure FAP phase free from other impurities. The experimental XRD patterns were simulated to obtain the lattice parameters $a=9.397 \AA, c=6.878 \AA, \alpha=90^{\circ}, \beta=90^{\circ}$, $\gamma=120^{\circ}$, lattice volume $V=525.96 \AA^{3}$ and space group $P 6_{3} / \mathrm{m}$. The relatively weak agreement was observed between the experimental and simulated structure (weighted residual error, $R_{\mathrm{wp}}=24 \%$ ) due to the presence of impurity phases. The different crystallographic sites of FAP can accommodate a variety of rare earth elements (REE) and radionuclides; therefore, one possible explanation may be due to the occupancy of the $\mathrm{Ca}(\mathrm{I})$ and $\mathrm{Ca}(\mathrm{II})$ sites by rare earth dopants (Nary Szabo 1930; Hughson and SenGupta 1964; Kay et al. 1964; Cockbain and Smith 1967; Mackie et al. 1972; Gunawardance et al. 1982).

The structure of FAP has been well reported in the literature (Nary Szabo 1930; Beevers and McIntyre 1946; White and Zhili 2003). The unit cell of FAP comprises 42 atoms with $4 \mathrm{Ca}(1), 5 \mathrm{Ca}(2)$, $6\left(\mathrm{PO}_{4}\right)$ and $2 \mathrm{~F}$ atoms. There are two crystallographically inequivalent $\mathrm{Ca}$ sites, $\mathrm{Ca}(\mathrm{I})$ and $\mathrm{Ca}(\mathrm{II})$, having a relative ratio of $60: 40$ and three inequivalent $\mathrm{O}$ atoms, a tetrahedral oxyanion $\mathrm{PO}_{4}^{3-}$ and a chain of fluorine along the $c$-axis. The point group symmetry of the $\mathrm{Ca}(\mathrm{I})$ site is $C_{3}$, with each $\mathrm{Ca}$ having six oxygen nearest neighbours that form a distorted triangular prism about the $\mathrm{Ca}^{2+}$ ion. The $\mathrm{Ca}(\mathrm{II})$ site has $C_{\mathrm{s}}$ symmetry with the $\mathrm{Ca}^{2+}$ ions sitting at the corners of equilateral triangles with an $\mathrm{F}$ ion in the centre. The hexagonal bipyramidal structure of FAP having non-centrosymmetric space group $P 6_{3} / m$ has been shown in the inset of figure 2(a). No distinct peaks corresponding to any uranium mineral were obtained indicating that uranium has been substituted at the lattice site rather than at the interstitial site.

\subsubsection{Haematite}

The XRD pattern of SH-9B (figure 2b) showed intense $2 \theta$ reflections at $24.23^{\circ}, 33.19^{\circ}, 35.79^{\circ}$, $40.89^{\circ}, 54.19^{\circ}, 62.47^{\circ}$ and $64.11^{\circ}$ corresponding to (012), (104), (110), (113), (116), (214) and (300) $h k l$ planes, respectively, indicating haematite to be the main phase (JCPDS \# 33-0664). The crystallographic parameters identified are structure: hexagonal; space group: $R 3 C$; lattice parameters $a=5.032 \AA, b=5.032 \AA, c=13.76 \AA, \alpha=90^{\circ}$, $\beta=90^{\circ}, \gamma=120^{\circ}$ and $V=301.78 \AA^{3}$ which are close to the values reported in the literature of pure haematite phase $a=b=5.038 \AA, c=13.77 \AA$, $V=302.72 \AA^{3}$ (Pauling and Henricks 1925; Willis and Rooksby 1952). Small $\left(R_{\mathrm{wp}}=13 \%\right)$ values of the structure refinement in the case of SH-9B suggest that the simulated XRD pattern agrees well with the measured XRD pattern and no impurity phases are observed within the detection limit of XRD.

\subsection{Raman spectroscopy}

Raman spectroscopy is a powerful tool to study the structural and vibrational property of a material that gives the useful information about cationic substitution and different phases (Jorge Villar et al. 2005). It can be used to study the submicron grain sizes of uranium species.

\subsubsection{Fluorapatite}

Raman spectra of samples $\mathrm{SH}-9 \mathrm{~W}$ are shown in figure 2(c). The modes corresponding to the stretching, translational and internal vibration modes of the $\mathrm{PO}_{4}$ groups are visible in the spectra. A strong band is observed at $964 \mathrm{~cm}^{-1}$ characteristic of the $v_{1}$ asymmetric stretching of the $\mathrm{PO}_{4}$ group while the bands at 1058 and 1083 correspond to $\mathrm{PO}_{4} v_{3}$ anti-symmetric stretching band and those at 403 and 439 to $v_{2}$ anti-symmetric stretching band (Comodi et al. 2001). However, no bands corresponding to the uranium species were visible.

\subsubsection{Haematite}

In the case of SH-9B (figure 2d) the representative bands of haematite are observed at 291, 232, 410, 493, 618 and $1322 \mathrm{~cm}^{-1}$ which are consistent with the XRD results (Hanesch 2009). The Raman spectral peak of haematite corresponds to a well-crystallised structure. The bands corresponding to $657 \mathrm{~cm}^{-1}$ indicated the presence of small amount of lepidocrocite $(\gamma-\mathrm{FeOOH})$. Haematite is a mineral formed by weathering process in the soils, hence there is a high possibility of it being present along with iron oxides such as lepidocrocite $(\gamma-\mathrm{FeOOH})$ or goethite $(\alpha-\mathrm{FeOOH})$. 


\subsection{FTIR spectroscopy}

The FTIR spectrum was used to determine the nature of functional groups which could possibly influence the adsorption of the uranium in the samples.

\subsubsection{Fluorapatite}

The FTIR spectra of SH-9W mainly demonstrated the vibrational modes for $\mathrm{PO}_{4}^{3-}$ and $\mathrm{CO}_{3}^{2-}$ in the FAP (figure 2e). Peaks at 470, 573, 601, 964, 1056, $1093 \mathrm{~cm}^{-1}$ are characteristic bands of the $\mathrm{PO}_{4}$ group (Stoch et al. 1997). The $\mathrm{P}-\mathrm{O}$ stretching has been observed at $960 \mathrm{~cm}^{-1}$ and $\mathrm{O}-\mathrm{P}-\mathrm{O}$ bending is observed at $470 \mathrm{~cm}^{-1}$, respectively. The other important characteristic peak of $\mathrm{PO}_{4}$ tetrahedral groups was the $\mathrm{P}-\mathrm{O}$ stretching $v_{3}$ vibration mode, which was visible at 1056 and $1093 \mathrm{~cm}^{-1}$. The bands at 572 and $601 \mathrm{~cm}^{-1}$ are the $v_{4}$ vibration mode of the phosphate group. In addition, a doublet appears at 1429 and $1490 \mathrm{~cm}^{-1}$ corresponding to the $v_{3}$ vibration mode and the band centred at $869 \mathrm{~cm}^{-1}$ for $v_{2}$ vibration mode of the carbonated groups. The peaks at 1999 and 2088 may be due to $\mathrm{PO}_{4}^{3-}$ overtones (Azami et al. 2011).

\subsubsection{Haematite}

Figure 2(f) revealed the vibrational spectra of SH-9B. The spectra revealed the characteristic bands of haematite between 470 and $550 \mathrm{~cm}^{-1}$ and are in agreement with past studies (Betancur et al. 2012). The other bands at 946 and 1056 $\mathrm{cm}^{-1}$ are due to symmetric stretching bands of the $\mathrm{PO}_{4}$ group due to the impurity phase of FAP in it. The presence of bands at $1632 \mathrm{~cm}^{-1}$ indicates $v_{2}$ bending modes of water, which proves structurally inequivalent water molecules in the crystal structure.

These characterisations confirm that SH-9W and SH-9B largely consist of FAP and haematite, and no signature of uranium species was evident.

\subsection{Surface morphology studies}

\subsubsection{Fluorapatite}

Figure 3(a) demonstrated the SEM image of SH-9W and it has been concluded that these crystals are dense euhedral crystals of hexagonal FAP formed due to homogeneous or heterogeneous crystallisations. Semi-quantitative analysis using
Energy Dispersive X-ray (EDX) revealed the Ca/P ratio of 1.76 in FAP.

\subsubsection{Haematite}

Figure 3(b) represented the rounded grains of haematite in SH-9B at $300 \mathrm{~nm}$ scale similar to that reported in the literature (Chung et al. 2014). The grain size appeared to be uniform and low porosity was visible indicating a well-crystallised structure.

Figure 3(c and d) indicates the SEM observations in backscattered (BSE) mode of SH-9 bulk sample revealing the presence of FAP, kaolinite and haematite at $300 \mu \mathrm{m}$ resolution. The measurements through BSE (EDX) revealed the presence of $\mathrm{Fe}, \mathrm{Ca}, \mathrm{P}$ along with the high concentration of rare earth ions; Eu, Dy, Ce and transition metal elements such as $\mathrm{Mn}, \mathrm{Mg}$ and actinides such as $\mathrm{U}$ and $\mathrm{Th}$.

\subsection{PL studies}

Luminescence spectroscopy is an ideal diagnostic tool for speciation of uranium when compared to other techniques such as XRD, electron paramagnetic resonance, Raman and chemical analysis due to its high sensitivity, specificity, simplicity, ease of operation and quick response (Morris et al. 1996; Catalano et al. 2004; Krepelova et al. 2007; Regensperg et al. 2010; Reitz et al. 2011; Baumann et al. 2012; Jones et al. 2015).

The difference in the spectral luminescence of $\mathrm{U}(\mathrm{IV})$ and $\mathrm{U}(\mathrm{VI})$ species helps in their detection and discrimination in the complex rock matrix. The PL studies were therefore conducted to identify different uranium species. The absorption spectrum of SH-9 sample is indicated in figure 4(a). SH-9 was excited by UV-Vis light corresponding to the basic and activated electronic and vibronic level of uranium and emission was monitored in the range $250-700 \mathrm{~nm}$. The absorption spectra exhibited a relatively broad and smeared out transition in the range $33,000-45,000 \mathrm{~cm}^{-1}$ without any distinct spectral peaks due to the greater radial overlap of $5 \mathrm{f}$ orbitals. These broad band features in the absorption spectra indicated the interconfigurational transitions between the $5 \mathrm{f}^{2}$ (ground state of uranium) and $5 \mathrm{f} 6 \mathrm{~d}$ states, namely $\mathrm{f}-\mathrm{d}$ transitions that occur in energy above $27,000 \mathrm{~cm}^{-1}$. The intense absorption spectra corresponding to the lowest energy level is observed at $230 \mathrm{~nm}(43,478$ $\mathrm{cm}^{-1}$ ), which is $15,000 \mathrm{~cm}^{-1}$ lower than that of 

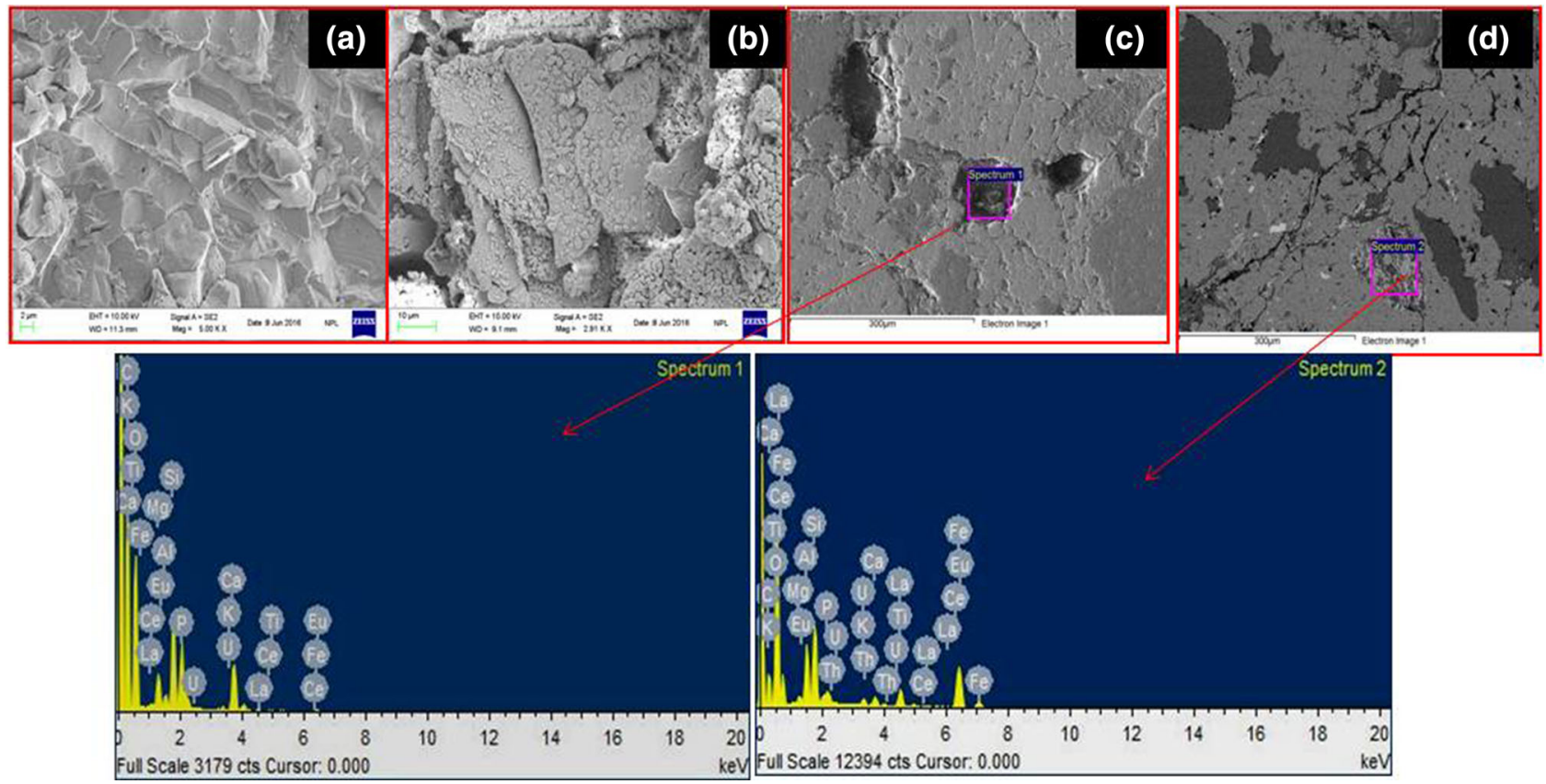

Figure 3. SEM micrograph of (a) magnified view of SH-9W, (b) magnified view of SH-9B, (c) the SEM micrograph, in BSE mode, of the whole rock sample of SH-9 (the arrow leads to the EDX spectrum revealing the presence of Eu, Dy, Na and Si within the material). (d) The SEM micrograph in BSE mode of the uranium adsorbed on kaolinite (the arrow leads to the EDX spectrum revealing the presence of actinides, $\mathrm{U}$ and $\mathrm{Th}$ ).

free $\mathrm{U}(\mathrm{V}),\left(\mathrm{U}^{4+}\right)$ ion since the lowest $\mathrm{f}-\mathrm{d}$ transition corresponding to $\mathrm{U}(\mathrm{V})$ is placed at $59,183 \mathrm{~cm}^{-1}$. The optical band gap of the sample was determined to be $4.5 \mathrm{eV}$.

\subsubsection{Fluorapatite}

Figure 5(a) shows the room temperature emission spectrum of SH-9W under excitation at $245 \mathrm{~nm}$. The spectral length was limited to $450 \mathrm{~nm}$ to avoid second-order diffraction peak due to the excitation wavelength. The deconvolution of the emission spectra revealed sharp peaks at 290, 313, 348 and $399 \mathrm{~nm}$.

The spectral effects could be explained by the $5 \mathrm{f}-6 \mathrm{~d}$ orbital hybridisation of uranium under the influence of crystal field. Several other studies have also reported the similar luminescence of U(IV) and U(III) covalent compounds in different crystal field symmetry and matrices; $\mathrm{U}^{4+}$ in $\mathrm{Cs}_{2} \mathrm{UCl}_{6}$ ( $O_{\mathrm{h}}$ symmetry) (Satten et al. 1965), $\mathrm{U}^{4+}$ in $\mathrm{UCl}_{4}$ and $\mathrm{ThCl}_{4}\left(D_{2 \mathrm{~d}}\right.$ symmetry) (Malek et al. 1984), [Li(THF $\left.)_{4}\right]\left[\mathrm{UCL}_{5}(\mathrm{THF})\right] \quad\left(C_{4 \mathrm{v}}\right.$ symmetry) (Hashem et al. 2013), $\mathrm{U}^{4+}$ in $\mathrm{UF}_{4}$ (Carnell et al. 1991), U ${ }^{4+}$ doped $\mathrm{LiYF}_{4}$ single crystal (Godbole et al. 2001), $\mathrm{U}^{4+}$ doped into $\mathrm{YF}_{3}$ single crystal (Kirm et al. 2003) and sulphate complexes in a frozen matrix (Görller-Walrand et al.
1993). The luminescence of uranium in natural apatites with ca. $308 \mathrm{~nm}$ peak and emission in the wavelength range of 400-800 $\mathrm{nm}$ were observed by Panczer et al. (1998).

Uranium has a ground state electronic configuration of $5 \mathrm{f}^{3} 6 \mathrm{~d}^{1} 7 \mathrm{~s}^{2}$. Uranium (V) has two unpaired electrons in the $5 \mathrm{f}$ state and electronic ground state of uranium is ${ }^{3} \mathrm{H}_{4}$. These emission spectra might be assigned to either excitation into a band of $\mathrm{f}-\mathrm{d}$ and ligand to metal charge transfer character followed by energy transfer from the $5 \mathrm{f}-6 \mathrm{~d}$ electronic configurations to envelopes of states arising from the ground state $5 \mathrm{f}^{2}$ configuration or due to the $\mathrm{f}-\mathrm{f}$ transitions from ${ }^{1} \mathrm{~S}_{0}$ to lower $5 \mathrm{f}$ levels of uranium (Hashem et al. 2013). Both these intraconfigurational $\mathrm{f}-\mathrm{f}$ transitions and interconfigurational charge transfer transition occur in the similar time span. However, the characteristic excitation band corresponding to the emission at ca. $313 \mathrm{~nm}$ is quite broad (figure 4b) and the excitation wavelength is observed at $230 \mathrm{~nm}$ which corresponds to $5 \mathrm{f}^{2}-5 \mathrm{f} 6 \mathrm{~d}$ transition (Kirishima et al. 2004). The interconfigurational $5 \mathrm{f}^{1} 6 \mathrm{~d}-5 \mathrm{f}$ transitions are parity allowed unlike $5 \mathrm{f}-5 \mathrm{f}$ transitions which are parity forbidden. They are characterised by short emission lifetimes and emission bands of high intensity located in the UV range. Radiative transitions from $5 \mathrm{f} 6 \mathrm{~d}$ to ${ }^{3} \mathrm{H}_{5},{ }^{3} \mathrm{~F}_{3},{ }^{3} \mathrm{H}_{6}$ and ${ }^{3} \mathrm{P}_{0}$ 

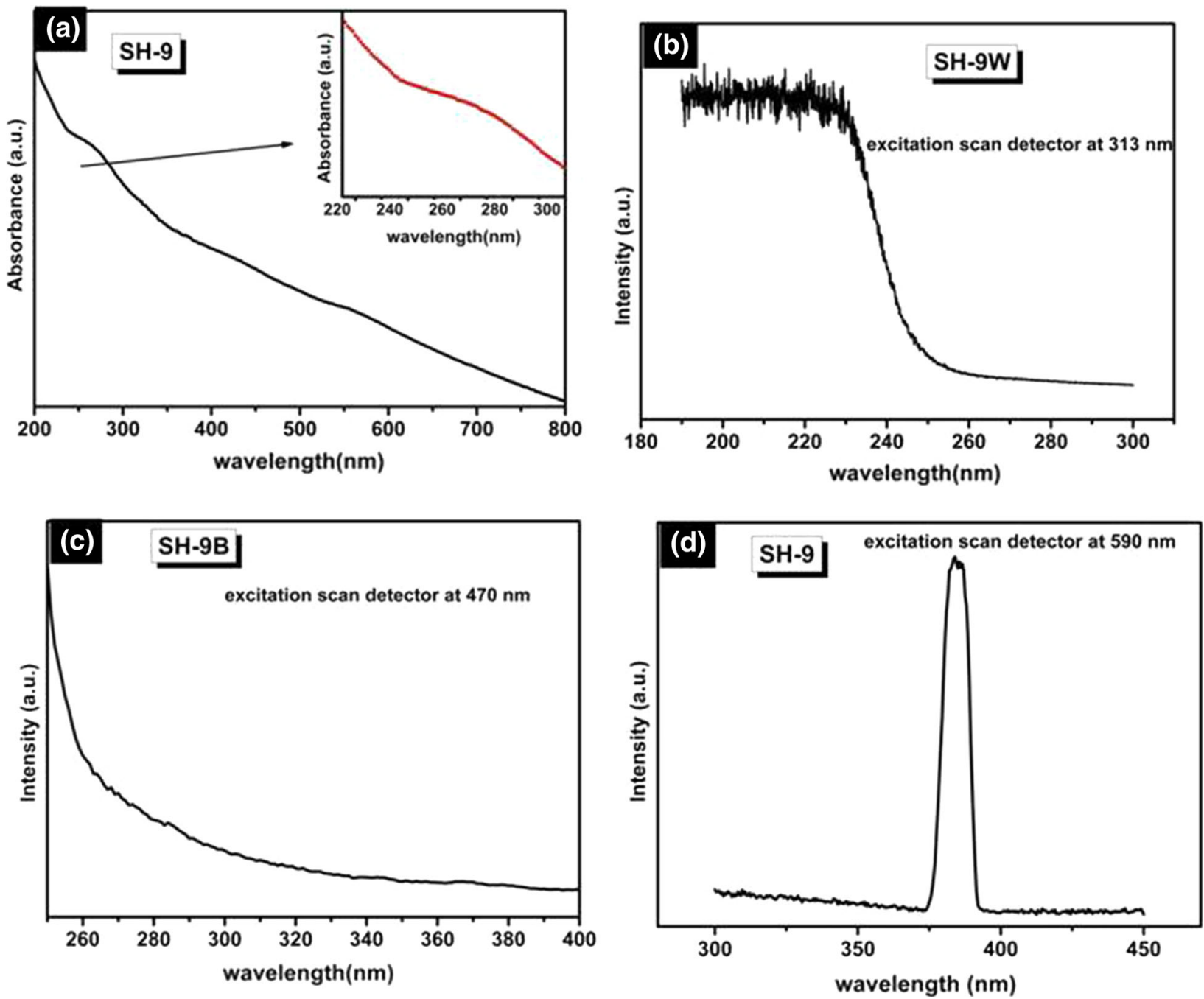

Figure 4. (a) UV-vis-NIR spectra of SH-9 showing the overlap of charge transfer band due to $5 \mathrm{f}^{2}-5 \mathrm{f} 6 \mathrm{~d}$ and oxygen $2 \mathrm{p}$ to uranium 6d orbitals. (b) PL excitation of SH-9W (detector at $313 \mathrm{~nm}$ ), (c) PL excitation of SH-9B (detector at 470 nm) and (d) PL excitation of SH-9 while keeping the detector at $590 \mathrm{~nm}$ showing the characteristic excitation peak of Eu.

resulted in emission peaks at ca. 290, 313, 348 and $399 \mathrm{~nm}$. The positions of the energetic bands are dependent on the coordination environment, crystal field symmetry and the excitation wavelength of the material. Figure 6 shows the band energy diagram of $\mathrm{U}^{4+}$ ion (Kirishima et al. 2004).

With regard to the crystal field, the two calcium positions of FAP have different stereochemistry and are able to accommodate a variety of monovalent $\left(\mathrm{Na}^{+}, \mathrm{K}^{+}\right)$, divalent $\left(\mathrm{Sr}^{2+}, \mathrm{Pb}^{2+}, \mathrm{Ba}^{2+}\right.$, $\mathrm{Mn}^{2+}$ and $\left.\mathrm{Cd}^{2+}\right)$, trivalent rare earth element $\left(\mathrm{REE}^{3+}\right)$ and tetravalent actinide $\left(\mathrm{Th}^{4+}\right.$ and $\left.\mathrm{U}^{4+}\right)$ cations (Luo et al. 2009). The Ca site occupancy of rare earth and the actinide substituted FAP ions is controlled by the bond valence, charge compensation mechanism and the radius constraints. The $\mathrm{Ca}(\mathrm{I})$ (effective radius $1.18 \AA$ ) site at the 4f Wyckoff position is described as having coordinated to nine oxygen atoms with point group symmetry $C_{3}$, whereas the $\mathrm{Ca}(\mathrm{II})$ sites in the $6 \mathrm{~h}$ Wyckoff positions (effective radius $1.06 \AA$ ) are eight coordinated to seven $\mathrm{O}$ atoms and one $\mathrm{F}$ atom having $C_{\mathrm{s}}$ symmetry (Elliott et al. 2002). According to Shannon (1976), the U(IV) in FAP having nine-fold coordination (effective radius $1.05 \AA$ ) substitutes at the $\mathrm{Ca}(\mathrm{II})$ position. The charge imbalance created by the substitution of higher valent $\mathrm{U}^{4+}$ is compensated by the coupled substitution involving $\mathrm{Na}^{+}, \mathrm{Si}^{4+}$ and vacancies (Elliott 1994). The compositional analysis of the samples in the EDX spectrum indicates the presence of both $\mathrm{Si}$ and $\mathrm{Na}$ in $\mathrm{SH}-9 \mathrm{~W}$ and $\mathrm{SH}-9 \mathrm{~B}$ (figure 3c and d). So, the local charge compensation may be maintained by the following coupled substitution in SH-9W: 
Page 9 of $16 \quad \mathbf{1 1 0}$

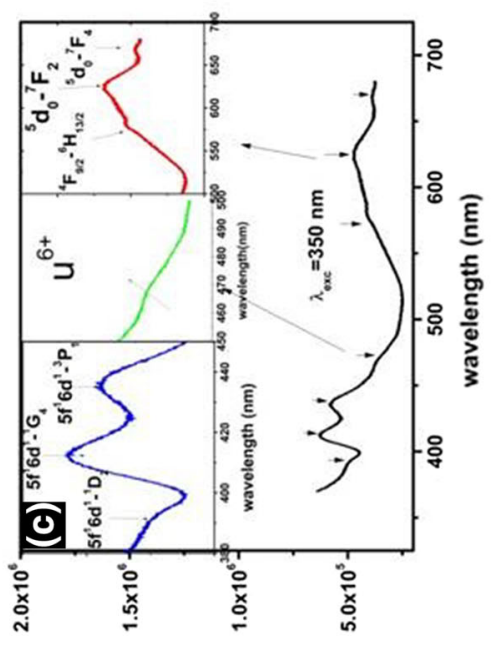

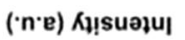

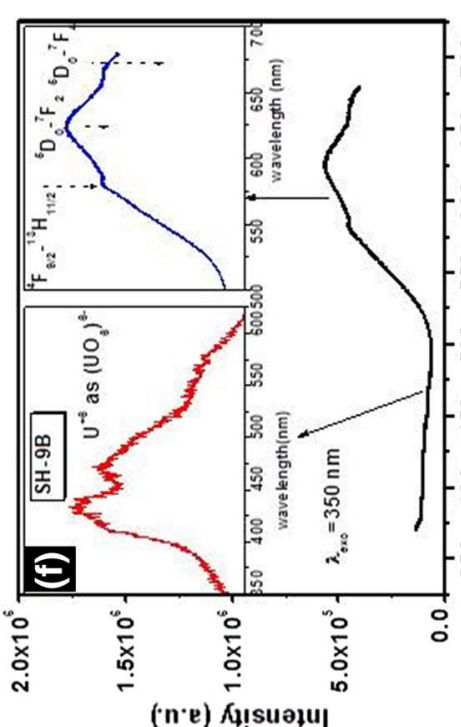

里染专

क t

范范范

苟.

$\approx$ 要

过

言

8 일

ही के

LD.

$\|$ 당

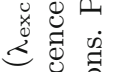

定. 苟离

थ 0 명

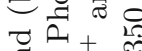

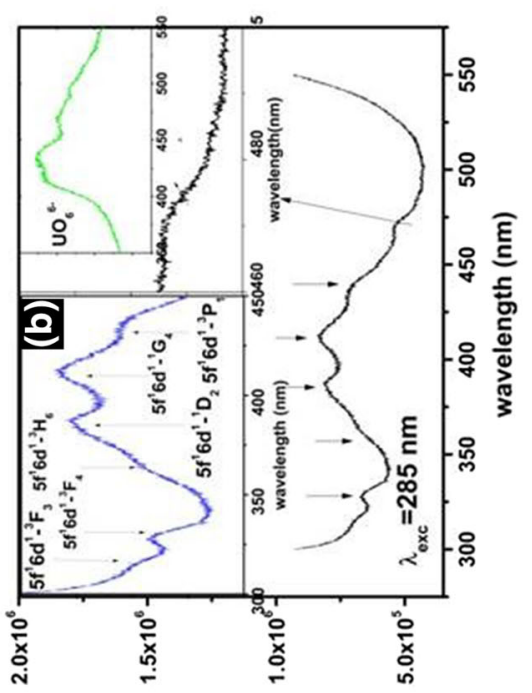

('n'e) K!!suəju|
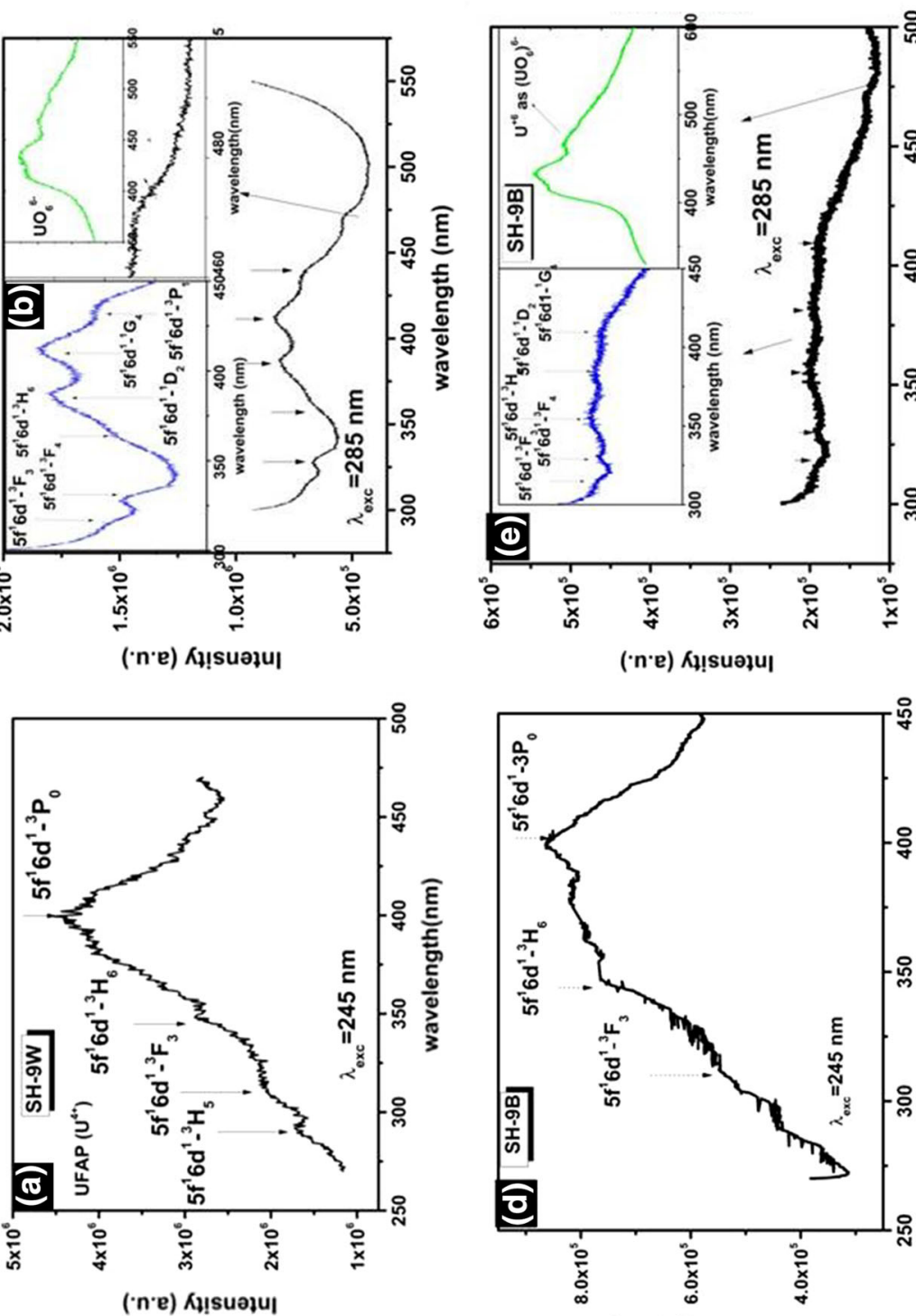

बن

द્वิ

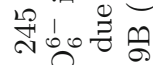

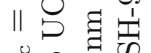

苑욜

t

专

का का

पे $.0 \%$

पू है त

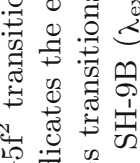

ป.

(n'e) K!! కuәวu

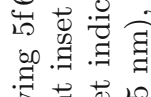

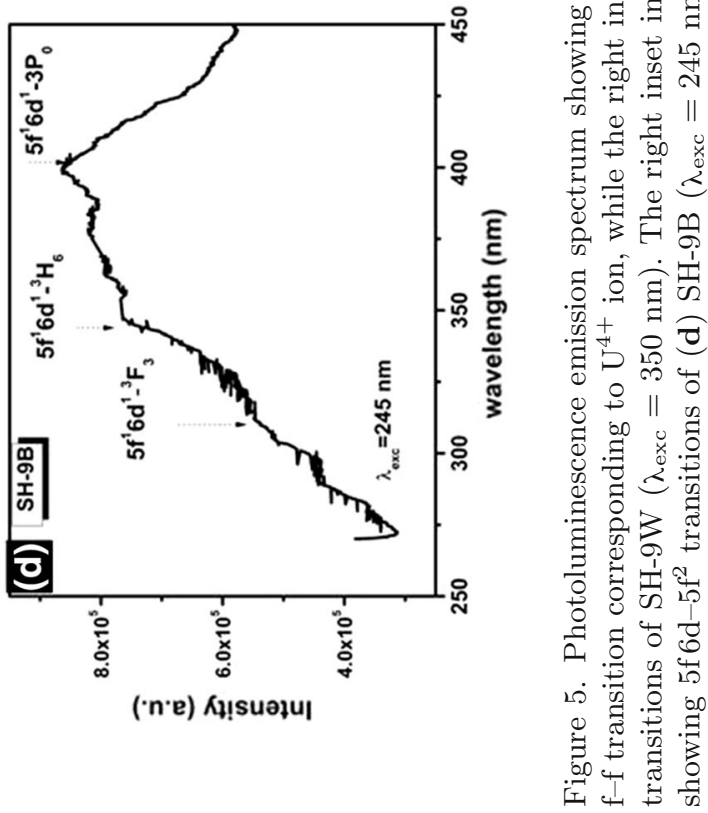




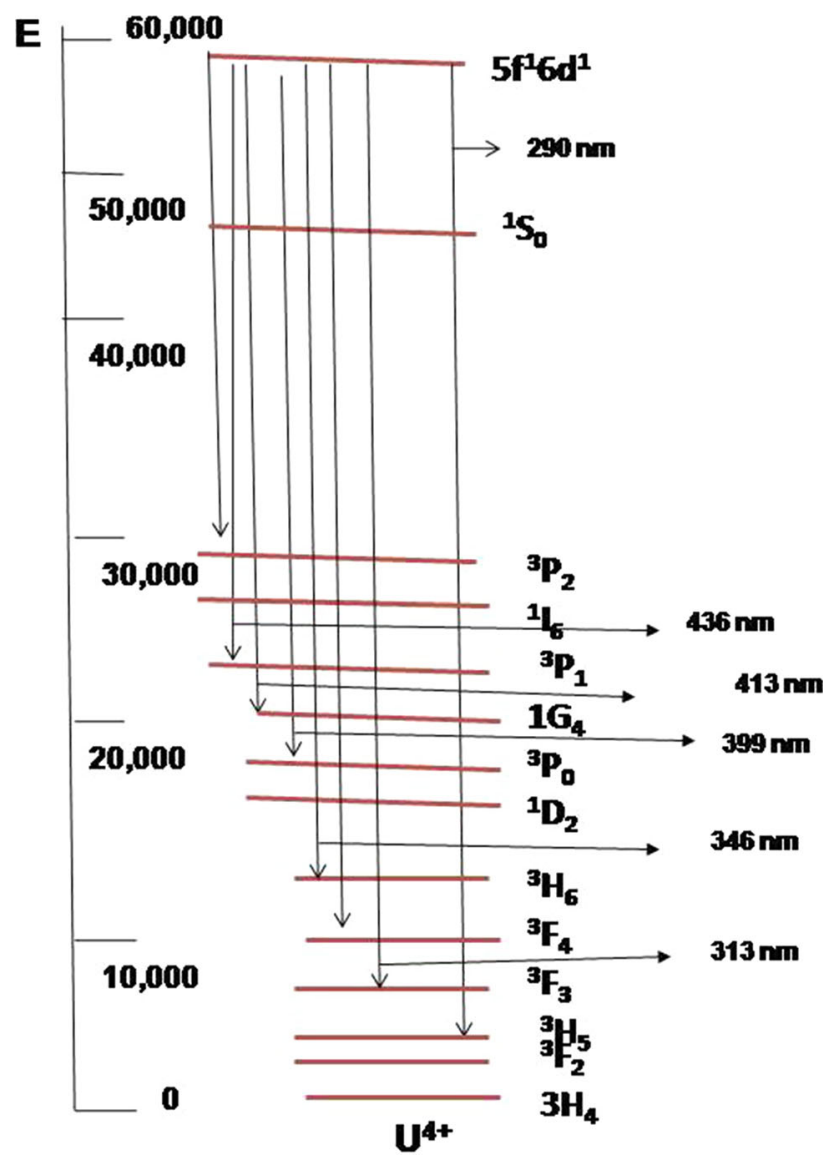

Figure 6. Band energy diagram of the $\mathrm{U}^{4+}$ ion.

$$
\begin{aligned}
\mathrm{M}^{4+}+[\text { vacancy }] & =2 \mathrm{Ca}^{2+} \\
\mathrm{M}^{4+}+2 \mathrm{Na}^{+} & =3 \mathrm{Ca}^{2+} \\
\mathrm{M}^{4+}+4 \mathrm{Na}^{+} & =5 \mathrm{Ca}^{2+}
\end{aligned}
$$

The emission spectra of SH-9W on being excited by 285 and $350 \mathrm{~nm}$ are shown in figure 5 (b and c), respectively.

The spectra of SH-9W under $285 \mathrm{~nm}$ excitation with a xenon lamp and filter at $335 \mathrm{~nm}$ can be deconvoluted into two structured emissions in the range 300-450 and 450-500 $\mathrm{nm}$ (figure 5b). The transitions at $313 \mathrm{~nm}\left(5 \mathrm{f}^{1} 6 \mathrm{~d}^{1} \_^{3} \mathrm{~F}_{3}\right), 319 \mathrm{~nm}$ $\left(5 \mathrm{f}^{1} 6 \mathrm{~d}^{1} \_^{3} \mathrm{~F}_{4}\right), 348 \mathrm{~nm}\left(5 \mathrm{f}^{1} 6 \mathrm{~d}^{1} \_^{3} \mathrm{H}_{6}\right), 409 \mathrm{~nm}\left(5 \mathrm{f}^{1} 6 \mathrm{~d}^{1}\right.$ $\left.{ }^{1} \mathrm{D}_{2}\right)$ and $448 \mathrm{~nm}\left(5 \mathrm{f}^{1} 6 \mathrm{~d}^{1}-^{3} \mathrm{P}_{1}\right)$ are attributed to the signature of $\mathrm{U}^{4+}$ as discussed above and an inhomogeneously broadened and smeared out emission spectrum without any band resolution in the spectral range $450-500 \mathrm{~nm}$ was observed. The second component of the emission spectra is similar to that exhibited by uranium in the hexavalent state U(VI). In the hexavalent state, uranium can exist as $\left(\mathrm{UO}_{2}\right)^{2+}$ or $\mathrm{U}(\mathrm{VI})$ in tetrahedral coordination: $\left(\mathrm{UO}_{4}\right)^{2-}$ or uranium in octahedral coordination: $\left(\mathrm{UO}_{6}\right)^{6-}$. While $\left(\mathrm{UO}_{4}\right)^{2-}$ emits in the orange-red region, both $\mathrm{UO}_{2}^{2+}$ and octahedral $\mathrm{UO}_{6}^{6-}$ emit in the green region. Both these uranyl and uranate emissions are electric dipole parity-forbidden transitions; however, $\mathrm{UO}_{2}^{2+}$ emission can be distinguished from that of the latter on the basis of its characteristic vibronic structure exhibiting a set of equidistant lines. The absence of vibronic structure clearly indicated that the transition intensity is from the electronic origin due to substantial electric dipole change during the electronic excitation at the low-symmetry site indicating the fact that the luminescence is from the uranate group. This is similar to the transition observed by U: $\mathrm{SrZO}_{3}$ and U: $\mathrm{SrB}_{4} \mathrm{O}_{7}$ (Tanner et al. 1997). The origin of this emission is assigned to the parity-forbidden charge transfer transition $5 \mathrm{f}-\mathrm{t}_{1 \mathrm{u}}$ that is vibronically coupled to ungerade vibrational modes of the $\mathrm{UO}_{6}^{6-}$ octahedron. The $\mathrm{U}(\mathrm{VI})$ may be present either as a substitution of Ca atom in FAP by $\mathrm{U}^{6+}$ or being adsorbed on $\mathrm{Fe}$ (III) as a uranate ion. In seven-fold coordination, considering the ionic radii of $\mathrm{Ca}^{2+}$ and $\mathrm{U}^{6+}(0.76 \AA)$, it was concluded that uranium mainly substituted at the $\mathrm{Ca}(\mathrm{II})$ position. The charge compensation in the case of $\mathrm{U}^{6+}$ substitution in FAP takes place according to the following formula:

$$
\begin{aligned}
& \mathrm{M}^{6+}+2 \mathrm{Si}^{4+}=\mathrm{Ca}^{2+}+2 \mathrm{P}^{5+}, \\
& \mathrm{M}^{6+}+2 \mathrm{Si}^{4+}=\mathrm{Ca}^{2+}+4 \mathrm{P}^{5+} .
\end{aligned}
$$

On excitation with $350 \mathrm{~nm}$ laser, two spectral components arise from three chemically different species in SH-9W (figure 5c). The mathematical fit to the emission decay curve for the first component signified peaks at 329, 386, 413 and $436 \mathrm{~nm}$ which are attributed to $\mathrm{U}^{4+}$ to that observed in the case of $245 \mathrm{~nm}$. The second component signified intense emission of red colour in the range 550-700 nm. These strong emissions at 578, 620 and $660 \mathrm{~nm}$ could be attributed to rare earth ions. The PL of rare earth ions originates from the electronic transitions in the $4 \mathrm{f}$ orbitals and the wavelength is independent of the host lattice. Fleet and Pan (1995) have noted that the structural role of REE in apatite remains unknown, as a given REE may be distributed over both the Ca sites. Further, Hughes et al. (1991) suggested that La to $\mathrm{Pr}$ ions should prefer the low-symmetry Ca(II) position, whereas $\mathrm{Pm}$ to $\mathrm{Sm}$ should occupy the $\mathrm{Ca}(\mathrm{I})$ position. The red emission at 620 and 669 $\mathrm{nm}$ is related to the electronic radiative ${ }^{5} \mathrm{D}_{0}-{ }^{7} \mathrm{~F}_{j}$ 
$(j=1,2,3,4)$ transition of the $\mathrm{Eu}^{3+}$ ions. This electric dipole radiation is otherwise forbidden by the Laporte selection rule. However, the transitions become permissible for $\mathrm{Eu}^{3+}$ occupancy at the $C_{\mathrm{s}}$ non-centrosymmetric site. The luminescence of $\mathrm{Eu}$ substituted apatite has been widely studied by Blasse (1975) and Gaft et al. (2001) and it has been observed that $\mathrm{Eu}^{3+}$ ions doped in apatite occupy mainly $\mathrm{Ca}$ (II) sites (Wright et al. 1995). The REE data performed using the ICPAES analysis revealed the corresponding values (La: 8 ppm; Ce: 15 ppm; Pr: <5 ppm; Nd: 7 ppm; Sm: 3 ppm; Eu: 0.8 ppm; Gd: 4 ppm; Tb $<2$ ppm; Dy: 3 ppm; Ho $<1$ ppm; Er: 2 ppm; Tm $<0.5$ ppm; Yb: 1.4 ppm; Lu<0.5 ppm; Y: 26 ppm). This was further confirmed by the observation of 578 $\mathrm{nm}\left({ }^{5} \mathrm{D}_{0}-{ }^{7} \mathrm{~F}_{0}\right)$ transition observed under $396 \mathrm{~nm}$ excitation. The emission peak at ca. $578 \mathrm{~nm}$ is due to the transition of $\mathrm{Dy}^{3+}$ between ${ }^{4} \mathrm{~F}_{9 / 2}$ and ${ }^{6} \mathrm{H}_{13 / 2}$ and is connected with $\mathrm{Dy}^{3+}$ in the $\mathrm{Ca}(\mathrm{II})$ site. Intense luminescence of this line is associated with the lower symmetry of the site.

Although XANES measurements have indicated $\mathrm{U}(\mathrm{IV})$ state for SH-9W, PL measurements have indicated both $\mathrm{U}(\mathrm{IV})$ and $\mathrm{U}(\mathrm{VI})$ states for both the samples which are due to the higher sensitivity of PL when compared to XANES.

Figure 4(b) showed the excitation spectra of SH-9W corresponding to the emission bands at 313,336 , and $400 \mathrm{~nm}$. The excitation spectra corresponds to the broad band extending from 190 to $250 \mathrm{~nm}$. The excitation spectra due to the emission at $470 \mathrm{~nm}$ (figure 4c) also revealed the similar features. Hence, the excitation spectra can be explained due to the charge transfer transition from oxygen $(2 \mathrm{p})$ to uranium $(6 \mathrm{~d})$ orbitals.

\subsubsection{Haematite}

Figure 5(d) shows the PL emission spectrum of $\mathrm{SH}-9 \mathrm{~B}$ in the range $250-450 \mathrm{~nm}$ at an excitation of $245 \mathrm{~nm}$. The feeble emission peaks in the near UV region are due to the impurity phase of FAP in SH-9B. The emission spectra noted at $285 \mathrm{~nm}$ excitation by keeping a filter at $335 \mathrm{~nm}$ revealed a structureless emission at $470 \mathrm{~nm}$ (figure 5e). As we have discussed earlier, from the nature of the luminescence, this uranium moiety could be attributed to uranate $\left(\mathrm{UO}_{6}\right)^{6-}$ ion. Since SH-9B majorly consists of haematite and other iron oxy(hydro) oxides, goethite and lepidocrocite are known to be effective at reducing the mobility of $\mathrm{U}(\mathrm{VI})$ through either their high adsorption capacity (surface adsorption) or, where $\mathrm{Fe}(\mathrm{II})$ is present, via reductive precipitation to poorly soluble U(IV) phase (Hsi and Langmuir 1985; Dzombak and Morel 1990; Waite et al. 1994; Finch and Murakami 1999; Dodge et al. 2002), hence the $\left(\mathrm{UO}_{6}\right)^{6-}$ ion may be either adsorbed or substituted at the structure. Earlier studies by Duff and Massey have observed uranium coprecipitation with iron oxides with the incorporation of a uranate species $\left(\mathrm{U}^{6+}\right)$ in the haematite structure (Duff et al. 2002; Elton et al. 2012; Massey et al. 2014). U(VI) (ionic radius $=0.870 \AA$ ) substitutes for $\mathrm{Fe}(\mathrm{III})$ (ionic radius $=0.785 \AA$ ) in octahedral sites and charge compensation is achieved through protonation/deprotonation of nearby hydroxyls, or the introduction of structural vacancies at cation sites hence it is contemplated that $\left(\mathrm{UO}_{6}\right)^{6-}$ ion has substituted at the $\mathrm{Fe}(\mathrm{III})$ site in the haematite structure.

The origin of emissions at 611 and $669 \mathrm{~nm}$ on excitation with $350 \mathrm{~nm}$ in SH-9B (figure 5f) of transitions is due to the presence of $\mathrm{Eu}$ ions present in FAP at lower symmetry site $C_{\mathrm{s}}$. The excitation spectra of SH-9 while keeping the detector at 590 $\mathrm{nm}$ revealed the characteristic $\mathrm{f}-\mathrm{f}$ transition corresponding to the ${ }^{7} \mathrm{~F}_{0}-{ }^{5} \mathrm{~L}_{6}$ transition of $\mathrm{Eu}^{3+}$ ions (figure 4d). PL emission indicated the presence of $\mathrm{U}(\mathrm{IV})$ and $\mathrm{U}(\mathrm{VI})$ species apart from the rare earth ions.

\subsection{Time-resolved photoluminescence}

\subsubsection{Fluorapatite}

The TRPL decay curves of SH-9W at 313 and 336 $\mathrm{nm}$ and that of SH-9B at $470 \mathrm{~nm}$ are shown in figure $7(\mathrm{a}-\mathrm{c})$, respectively. We note that the lifetimes are biexponential components when deconvolution of the data is employed giving lifetime values in the range of $2-10$ ns. The decay curves were fitted with a biexponential function using the equation where $A_{1}$ and $A_{2}$ are pre-exponential factors and $\tau_{1}$ and $\tau_{2}$ stand for the lifetime of fast and slow decays, respectively. The observed effective lifetime $\tau$ for biexponential decays for SH-9W is $\tau_{1}=2.04 \pm$ $0.014 \mathrm{~ns}(67 \%)$ and $\tau_{2}=0.43 \pm 0.002 \mathrm{~ns}(34 \%)$ at $313 \mathrm{~nm} ; \tau_{1}=4.19 \pm 0.022 \mathrm{~ns}(70 \%)$ and $\tau_{2}=0.64 \pm$ $0.008 \mathrm{~ns}(30 \%)$ at $336 \mathrm{~nm}$ typical of U(IV) species. For U(IV) species, multi-exponential decays hinting at complex deactivation or multiple excited states have already been observed (Hashem et al. 2013). However, we have observed the biexponential decay indicating the presence of two distinct U(IV) species. This biexponential decay could 

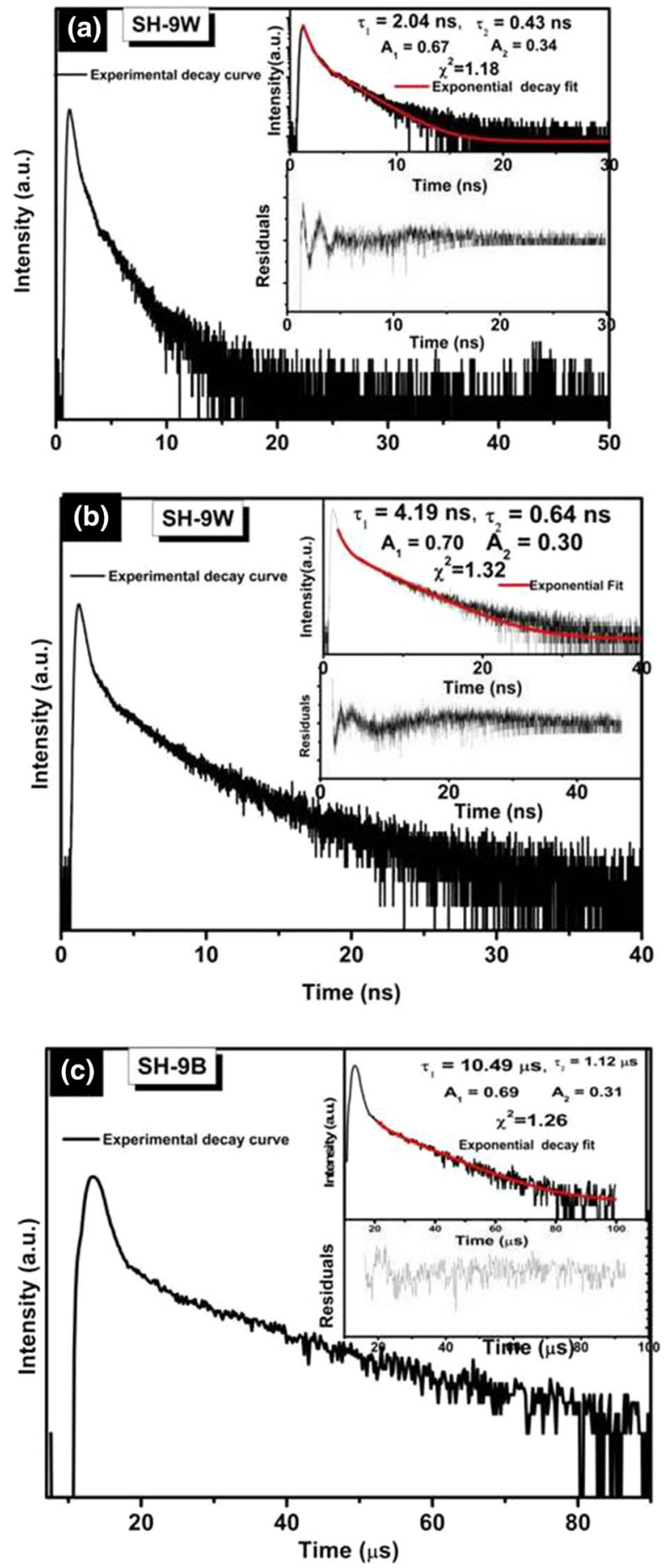

Figure 7. TRPL decay profile of (a) SH-9W at $313 \mathrm{~nm}$ emission (the inset shows the lifetime data and the parameters generated by exponential fitting), (b) at $336 \mathrm{~nm}$ emission, (c) at $470 \mathrm{~nm}$ emission (all the spectra were acquired at $285 \mathrm{~nm}$ excitation).

have arised due to the stabilisation of U(IV) in two coordination environments; either $\mathrm{Ca}(\mathrm{I})$ in seven-fold coordination or $\mathrm{Ca}$ (II) in nine-fold coordination.

\subsubsection{Haematite}

The decay measurements of SH-9B at $470 \mathrm{~nm}$ (figure $7 \mathrm{c}$ ) revealed two different decay times in the range of $\mu \mathrm{s}$, characteristic of uranate ion. The lifetime values obtained are $10.49 \mu \mathrm{s}(69 \%)$ and $1.12 \mu \mathrm{s}(31 \%)$. The uranium in uranyl form has a lifetime in the range of 100s of $\mu \mathrm{s}$; however, in the present case the lifetime has clearly indicated that the uranium is present as a uranate ion.

\section{$4.7 U L_{\mathrm{III}}$-edge $X A N E S$ analysis}

XAS containing XANES has become a wellestablished tool for oxidation state determination of actinides. XANES has been carried out on SH$9 \mathrm{~W}$ and $\mathrm{SH}-9 \mathrm{~B}$ uranium $\mathrm{L}_{\mathrm{III}}$ edge absorption in the fluorescence mode. The calibration for energy was performed by measuring the edges of the natural reference samples; Rutherfordine $\left(\mathrm{UO}_{2} \mathrm{CO}_{3}\right)$ for $\mathrm{U}(\mathrm{VI})$ and uraninite $\left(\mathrm{UO}_{2}\right)$ for $\mathrm{U}(\mathrm{IV})$, the inflection points of which were obtained at 17,168.2 and $17,165.3 \mathrm{eV}$, respectively.

\subsubsection{Fluorapatite}

In the case of the spectra for $\mathrm{SH}-9 \mathrm{~W}, \mathrm{U} \mathrm{L}_{\mathrm{III}}$-edge edge jump position $(\mathrm{eV})$ is obtained at $17,163.9$ $\mathrm{eV}$ indicating that uranium in FAP-rich portion is present in the tetravalent state, U(IV) state, which implies that either $\mathrm{U}^{4+}$ has substituted $\mathrm{Ca}^{2+}$ ions (figure 8a).

\subsubsection{Haematite}

The $\mathrm{U} \mathrm{L}_{\mathrm{III}}$-edge jump position $(\mathrm{eV})$ for $\mathrm{SH}-9 \mathrm{~B}$ has been obtained at $17,167.9 \mathrm{eV}$ which is similar to $\mathrm{UO}_{2} \mathrm{CO}_{3}$ standard, revealing that SH-9B has $\mathrm{U}(\mathrm{VI})$ oxidation state (figure $8 \mathrm{~b}$ ). Around the postedge region, multiple resonance features such as a 'shoulder' are usually observed in U(VI) XANES spectra. This feature is often attributed to the structural coordination environment around the $\mathrm{U}(\mathrm{VI})$ atom, which usually exists as the dioxo linear moiety (a $\mathrm{UO}_{2}^{2+}$ ion group). Most $\mathrm{U}(\mathrm{VI})$ solids and solution species have a coordination number (CN) of 6-8 (Weigel 1986; Burns et al. 1996; Duff et al. 2000), whereas $\mathrm{U}(\mathrm{IV})$ in $\mathrm{UO}_{2}$ (s), e.g., usually has a CN of eight or nine, and does not have a 'shoulder'. Since XANES spectra of SH9B have a very similar shoulder at the post-edge side as $\mathrm{UO}_{2} \mathrm{CO}_{3}$ XANES standard of $\mathrm{U}(\mathrm{VI})$ which indicated that uranium has the possible local coordination of octahedral or close to it. However, the 

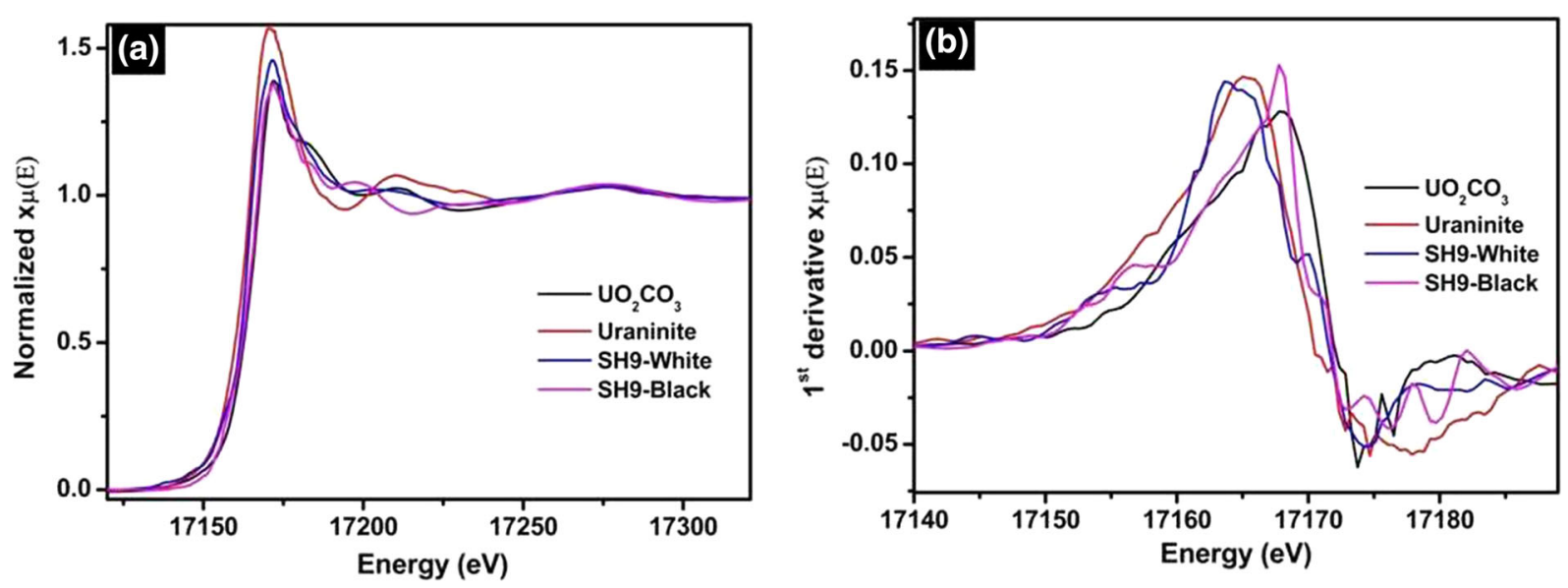

Figure 8. (a) U L LII-edge XANES spectra of 4+, 6+ and SH-9W, SH-9B samples and (b) first derivative of XANES spectra.

studies have suggested that $\mathrm{U}(\mathrm{VI})$ in the form of $\mathrm{UO}_{6}^{6-}$ replaces the $\mathrm{Fe}^{3+}$ ion.

Mössbauer studies conducted on the above sample have indicated the presence of $\mathrm{Fe}$ in $\mathrm{Fe}(\mathrm{III})$ oxidation state which indirectly points to the presence of uranium in the hexavalent form since the oxidation potential for $\mathrm{U}(\mathrm{IV}) / \mathrm{U}(\mathrm{VI})$ is considerably lower than for $\mathrm{Fe}(\mathrm{II}) / \mathrm{Fe}$ (III) couple (see the supplementary figure S2). The corresponding values of the isomer shift and the hyperfine field (table S1) indicated the magnetic field due to haematite and iron hydroxides (see supplementary information).

\subsection{Remediation}

Uranium being radiologically and chemically toxic is a big environmental hazard and earlier studies have revealed that people living in phosphatic mining zone had higher concentration of uranium in their blood rather than the people staying in urban dwelling (Menzel 1968; Philip et al. 1979; Cevik et al. 2010; Albedri et al. 2014; Sahu et al. 2014).

With respect to the above characterisation data, the strategies for remediation should be devised based on the presence of uranium as a substituent in the structure and also on its adsorption on silica and other clay minerals. Due to the entrapment of the uranium in the structure of haematite and FAP, leaching with mild complexing agents such as sodium bicarbonate solutions and citric acid will not serve the purpose. Encapsulation of the soil with cement and lime will also be less effective in remediating the uranium from the structure. Besides, these would cause a negative effect on the structure and composition of the soils. However, these remediation studies will work in the case of uranium being adsorbed on silica and other clay minerals. Since no prominent hexavalent uranium species has been noted this implies that magnetic separation will not work.

A cost-effective strategy for the remediation of these lands would be phytoremediation and bioremediation. Since the Bijawar region is devoid of any organic species and plant nutrients hence phytoremediation will not serve the purpose. In bioremediation, the $\mathrm{U}(\mathrm{VI})$ reducing microorganism such as Desulfovibrio desulfuricans, Pseudomonas aeruginosa and Rhizopus arrhizus are effective in leaching out uranium from low- and intermediate-grade uranium reserves. These bacteria reduce $\mathrm{U}(\mathrm{VI})$ to $\mathrm{U}(\mathrm{IV})$ and also solubilise elements as a result of acid production. The microbial communities that are effective in this process are Geobacteracae. Besides, the bioremediation is an environment-friendly process unlike leaching with other chemical agents. The process is highly effective in cases where other remediation techniques will not work.

\section{Conclusion}

To summarise, extensive mineralogical and spectroscopic characterisations have been carried out on the uraniferous mineral concentrate portion obtained from the phosphatic rocks of the Bijawar region for speciation of uranium in this region. The structural characterisation identified FAP and haematite to be the main phases in the mineral concentrate portions along with traces of calcite. The powder X-ray diffractometry confirmed the hexagonal structure of the FAP material with lattice parameters $a=9.397 \AA$ and $c=6.884 \AA$. 
Haematite is also identified to be of hexagonal structure with lattice parameters $a=5.032 \AA$, $b=5.032 \AA, c=13.76 \AA$. Functional groups of two phases have been confirmed by FTIR and Raman spectroscopy. Molecular spectroscopic studies have indicated both the hexavalent and tetravalent oxidation states for uranium in these mineral concentrate samples. The PL data from the subsurface sample has indicated that in the tetravalent state, $\mathrm{U}^{4+}$ is identified to be substituted at the $\mathrm{Ca}(\mathrm{II})$ sites in the FAP. In the hexavalent U(VI) state, it is identified in the form of uranate ion $\left(\mathrm{UO}_{6}\right)^{6-}$ potentially as a substituent of the $\mathrm{Ca}^{2+}$ ion in FAP and that of $\mathrm{Fe}^{3+}$ ion in haematite and finally as $\left(\mathrm{UO}_{2}\right)^{2+}$ adsorbed on silica. The fluorescence decay lifetime studies carried out by TRPL of the $5 \mathrm{f} 6 \mathrm{~d}-$ $5 \mathrm{f}^{2}$ transition for $\mathrm{U}^{4+}$ : FAP was measured to be 2-4 ns. In the hexavalent U(VI) state, fluorescence lifetime decay was calculated to be of the order of $10 \mu \mathrm{s}$. Lifetime studies carried out by TRPL and the oxidation state analysis by XANES further corroborated the PL findings. This study aims to provide a spectral database of uranium species in the Bijawar region. Based on the above characterisation data, bioremediation is identified to be an effective strategy for remediation in this area.

\section{Acknowledgements}

The authors deeply acknowledge Ms. Parasmani Rajput and Mr S N Jha, RRCAT, Indore for their help in XANES measurement and Mr Raghvendra Reddy, IUC, Indore for his help in Mössbauer measurements. The authors also like to thank Mr A K Rai, the Director, AMD, for granting the permission to pursue this project.

\section{References}

Albedri M B, Arar H A and Hameed W O 2014 Determination of natural radioactivity levels in surface soils of old phosphatic mines at Russaifa of Jordan; Int. J. Phys. Res. 4 31-38.

Azami M, Mozafari S M and Rabiee M 2011 Synthesis and solubility of calcium fluoride/hydroxy-fluorapatite nanocrystals for dental applications; Ceram. Int. 37 2007-2014.

Banerjee D M, Khan M W Y, Shrivastav N and Saigal G C 1982 Precambrian phosphorites in the Bijawar rocks of Hirapur-Bassia areas, Sagar district Madhyapradesh; India Miner. Deposita 17 349-362.

Baumann N, Arnold T and Lonschinski M 2012 TRFLS study on speciation of uranium in seepage water and pore water of heavy metal contaminated soil; J. Radioanal. Nucl. 291 673-679.

Beevers C A and McIntyre D B 1946 The atomic structure of fluorapatite and its relation to that of tooth and bone material; Miner. Mag. 27 254-257.

Betancur A F, Pérez F R, Correa M, Del M and Barrero C A 2012 Quantitative approach in iron oxides and oxyhydroxides by vibrational analysis; Opt. Pura. Appl. 45(3) 269-275.

Blasse G 1975 Influence of local charge compensation on site occupation and luminescence of apatites; J. Solid State Chem. 14(2) 181-184.

Burns P C, Miller M L and Ewing R C $1996 \mathrm{U}^{6+}$ minerals and inorganic phases: A comparison and hierarchy of crystal structures; Can. Miner. 34 845-880.

Carnell W T, Liu G K, Williams C W and Reid M F 1991 Analysis of the crystal-field spectra of the actinide tetrafluorides $\mathrm{UF}_{4}, \mathrm{NpF}_{4}$, and $\mathrm{PuF}_{4} ;$ J. Chem. Phys. 95 7194-7203.

Catalano J G, Heald S M, Jachara J M and Brown G E Jr 2004 Spectroscopic and diffraction studies of Uranium speciation in contaminated Vandose Zone sediments from the Hanford Site, Washington State; Environ. Sci. Technol. 38 2822-2828.

Cevik U, Baltas H, Tabak A and Damla N 2010 Radiological and chemical assessment of phosphate rocks in some countries; J. Hazard. Mater. 182 531-535.

Chung C W, Chun J, Wang G and Um W 2014 Effect of iron oxides on the rheological properties of cementitious slurry; Colloids Surf. A 453 94-100.

Cockbain A G and Smith G V 1967 Alkaline-earth-rare-earth silicate and germanate apatites; Mineral. Mag. 36 411421.

Comodi P, Liu Y and Frezzotti M L 2001 Structural and vibrational behaviour of Fluoroapatite with pressure: Part II. In-situ micro Raman spectroscopic investigation; Phys. Chem. Miner. 28 225-231.

Dar S A, Khan K F, Khan S A, Mir A R, Wani $\mathrm{H}$ and Balaram V 2014a Uranium (U) concentration and its genetic significance in the phosphorites of the Paleoproterozoic Bijawar Group of the Lalitpur district, Uttar Pradesh, India; Arab J. Geosci. $72237-$ 2248 .

Dar S A, Khan K F, Khan Saif A, Khan S and Alam M M 2014b Petromineralogical studies of the paleoproterozoic Phosphorites in the Sonrai basin, Lalitpur District, Uttarpradesh, India; Nat. Resour. Res. 24339 348.

Dodge C J, Francis A J, Gillow J B, Halada G P, Eng C and Clayton C R 2002 Association of uranium with iron oxides typically formed on corroding steel surfaces; Environ. Sci. Technol. 36 3504-3511.

Duff M C, Morris D E, Hunter D B and Bertsch P M 2000 Spectroscopic characterization of uranium in evaporation basin sediments; Geochim. Cosmochim. Acta 64 15351550 .

Duff M, Coughlin J and Hunter D 2002 Uranium coprecipitation with iron oxide minerals; Geochim. Cosmochim. Acta 66 3533-3547.

Dzombak D A and Morel F M M 1990 Surface complexation modeling - Hydrous ferric oxide; 24, John Wiley \& Sons, New York. 
Elliott J C 1994 Structure and chemistry of the apatites and other calcium orthophosphates; Elsevier, New York.

Elliott J C, Wilson R M and Dowker S E P 2002 'Apatite Structures', JCPDS-International Centre for diffraction data; Adv. X-ray Anal. 45 172-181.

Elton E S, Pacheko J S, Bargar J R, Shi Z, Liu J, Kovarik L, Engelhard M H and Felmy A R 2012 Reduction of U(VI) incorporated in the structure of haematite; Environ. Sci. Technol. 46(17) 9428-9436.

Finch R and Murakami T 1999 Systematics and paragenesis of uranium minerals; In: Uranium: Mineralogy, geochemistry and the environment (eds) Burns P C and Finch R, Mineral. Soc. Am. 38 91-180.

Fleet M E and Pan Y 1995 Site preference of rare earth elements in fluorapatite; Am. Mineral. 80 329-335.

Gaft M, Panczer G, Reisfeld R and Uspensky E 2001 Laser-induced time-resolved luminescence as a tool for rare-earth element identification in mineral; Phys. Chem. Mineral. 28 347-363.

Godbole S V, Page A G, Sangeeta Sabharwal S C, Gesland J Y and Sastry M D 2001 UV luminescence of $\mathrm{U}^{4+}$ ions in $\mathrm{LiYF}_{4}$ single crystal: Observation of $5 \mathrm{f}^{1} 6 \mathrm{~d}^{1}-5 \mathrm{f}^{2}$ transition; J. Lumin. 93213.

Görller-Walrand C, Gos M P and D'Olieslager W 1993 The luminescence spectra of $\mathrm{UF}_{4}$ and $\mathrm{UCl}_{4} ;$ Radiochim. Acta 62 55-60.

Gunawardance R P, Howie R A and Glasser F P 1982 Structure of the oxyapatite $\mathrm{NaY}_{9}\left(\mathrm{SiO}_{6}\right) \mathrm{O}_{2} ;$ Acta Crystllogr. B 38 1564-1566.

Guzman E T R, Rios M S, Garcia J L I and Regil E O 1995 Uranium in phosphate rock and derivatives; J. Radioanal. Nucl. 189(2) 301-306.

Hanesch M 2009 Raman spectroscopy of iron oxides and (oxy)hydroxides at low laser power and possible applications in environmental magnetic studies; Geophys. J. Int. 177 941-948.

Hashem E, Swinburne A N, Schulzke C, Evans R C, Platts J A, Kerridge A, Natrajan L S and Baker R J 2013 Emission spectroscopy of uranium (IV) compounds: A combined synthetic, spectroscopic and computational study; $R S C$ Adv. 3 4350-4361.

Hsi C K D and Langmuir D 1985 Adsorption of uranyl on to ferric oxyhydroxides: Application of the surface complexation site-binding model; Geochim. Cosmochim. Acta 49 1931-1941.

Hughes J M, Cameron M and Mariano A N 1991 Rare-earth-element ordering and structural variations in natural rare-earth-bearing apatites; Am. Mineral. 76 $1165-1173$.

Hughson M R and SenGupta J G 1964 A thorian intermediate member of the britholite-apatite series; $A m$. Mineral. 49937.

Jha S K, Shrivastav J P and Bhairam C L 2012 Clay mineralogical studies in the bijawars of the Sonrai Basin: Paleoenvironmental implications and interferences on the uranium mineralization; J. Geol. Soc. India 79 $117-134$

Jones D L, Andrewa M B, Swinburne N, Botchway S W, Ward Andrew D and Lloyd J R 2015 Fluorescence spectroscopy and microscopy as tools for monitoring redox transformation of uranium in biological system; Chem. Sci. 6 5133-5138.
Jorge Villar S E, Edwards H G M and Worland M R 2005 Comparative evaluation of Raman spectroscopy at different wavelengths for extremophile exemplars; Orig. Life Evol. Biospheres 35 489-506.

Kay M I, Young R A and Posner A S 1964 Crystal structure of hydroxyapatite; Nature 204 1050-1052.

Kirishima A, Kimura T, Nagaishi R and Tochiyama O 2004 Luminescence properties of tetravalent uranium in aqueous solution; Radiochim. Acta 92 705-710.

Kirm M, Krupa J S and Makhov V N 2003 6d5f and 5f ${ }^{2}$ configurations of $\mathrm{U}_{4}$ doped into $\mathrm{LiYF}_{4}$ and $\mathrm{YF}_{3}$ crystal; J. Lumin. 104 85-92.

Krepelova A, Brendler V, Sachs S, Baumann N and Bernhard G 2007 U(VI) - Kaolinite surface complexation in absence and presence of humic acid studies by TRFLS; Environ. Sci. Technol. 41(17) 6142-6147.

Luo Y, Hughes J M, Rakovan J and Pan Y 2009 Site preference of U, F and Sr apatites; Am. Mineral. 94 345-351.

Mackie P E, Elliott J C and Young R A 1972 Monoclinic structure of synthetic Ca,(PO.),CI, chlorapatite; Acta Crystallogr. B 28 1840-1848.

Malek C K, Krupa J C and Guillamont R 1984 Spectra of $\mathrm{U}^{4+}$ ion at a site of D-2d symmetry; Inorg. Chim. Acta 94 92-95.

Massey M S, Lezama-Pacheco J S, Michel F M and Fendorf S 2014 Uranium incorporation into aluminum-substituted ferrihydrite during iron (II)-induced transformation; Environ. Sci. Process. Impact. 16 2137-2144.

Menzel R G 1968 Uranium, thorium and radium content in phosphate rocks and their possible radiation Hazard; $J$. Agric. Food. Chem. 16(2) 231-234.

Morris D E, Allen P G, Berg J M, Chisolm-Brause C J, Conradson S D, Donhoe R J, Hess N J, Musgrave J A, Drew Tait C and Nancy J 1996 Speciation of uranium in Fernald soils by molecular spectroscopic methods: Characterization of untreated soils; Environ. Sci. Technol. 30 $2322-2331$.

Murad E and Schwertmann U 1986 Influence of Al substitution and crystal size on the room temperature Mossabeur spectra of haematite; Clay Clay. Miner. 34 1-6.

Nary Szabo S 1930 The structure of apatite; Z. Kristallogr. 75 387-398.

Panczer G, Gaft M, Reufeld R, Shaval S, Boulan G and Chapagown B 1998 Luminiscence of uranium in natural apatites; J. Alloys Compd. 275-277 269-272.

Pauling L and Henricks S B 1925 The crystal structure of hematite and corundum; J. Am. Chem. Soc. 47(3) 781790.

Philip G, Fister H and Pauly H 1979 Occupational dose from natural radionuclides in phosphate fertilizers; Radiat. Environ. Biophys. 16 143-156.

Regensperg S, Margot-Roguier C, Froidevaux P, Steinmann P, Junier P and Bernier-Latmani R 2010 Speciation of naturally-accumulated uranium in an organic-rich soil of an alpine region (Switzerland); Geochim. Cosmochim. Acta 74 2082-2098.

Reitz T, Merroun M L, Rossberg A, Steudner R and Solenska-Pobell S 2011 Bioaccumulation of U(VI) by Sulfolobus acidocaldarius under moderate acidic conditions 99; Radiochim. Acta 9 543-554.

Roy M, Bagchi A K, Babu E V S S K, Mishra B and Krishnamurthy P 2004 Petromineragraphy and mineral chemistry 
of Bituminous Shale hosted uranium mineralization at Sonrai, Lalitpur district, Uttar Pradesh; J. Geol. Soc. India 63 291-298.

Sahu S K, Ajmal P Y, Bhangare R C, Tiwari M and Pandit G G 2014 Natural radioactivity assessment of a phosphate fertilizer plant area; J. Radiat. Res. Appl. Sci. 7 123128.

Satten R A, Schreiber C L and Wong E Y 1965 Energy levels of $\mathrm{U}^{4+}$ in an octahedral crystalline field; J. Chem. Phys. 42 162-171.

Shannon R D 1976 Revised effective ionic radii and systematic studies of interatomic distances in halides and chalcogenides; Acta. Crystallogr. A 32 751761.

Stoch A, Jastrzebski W, Brozek A, Trybalska B, Cichocinska M and Szarawar E 1997 FTIR monitoring of the growth of the carbonate containing apatite layers from simulated and natural body fluids; J. Mol. Struct. $511287-$ 294.

Corresponding editor: N V Chalapathi RAO
Tanner P A, Pei Z W, Jun L, Yulong L and Qiang S 1997 Luminiscence of uranium doped strotium borate $\left(\mathrm{SrB}_{4} 0_{7}\right)$; J. Phys. Chem. Solids. 58(7) 1143-1146.

Waite T D, Davis J A, Payne T E, Waychunas G A and Xu N 1994 Uranium (VI) adsorption to ferrihydrite: Application of a surface complexation model; Geochim. Cosmochim. Acta 58(24) 5465-5478.

Weigel F 1986 Uranium; In: The chemistry of the actinide elements; 2nd edn, Vol. 1 (eds) Katz J J et al., Chapman and Hall, Springer, Netherlands, Chap. 5, pp. 169-442.

White T J and Zhili D 2003 Structural deviation and crystal chemistry of apatites; Acta. Crystallogr. B 59 1-16.

Willis B T M and Rooksby H P 1952 Crystal structure and anti-ferromagnetism in Haematite; Phys. Soc. London B 65 950-962.

Wright A O, Seltzer M D, Gruber J B and Chai B H T 1995 Site-selective spectroscopy and determination of energy levels in $\mathrm{Eu}^{3+}$-doped strontium fluorophosphate; J. Appl. Phys. 78(4) 2456-2467. 